\title{
Detection of Lymnaea columella Infection by Fasciola hepatica through Multiplex-PCR
}

\section{Kelly Grace Magalhães, Liana Konovaloff Jannotti Passos, 0 mar dos Santos Carvalho+}

\author{
Centro de Pesquisas René Rachou-Fiocruz, Av. Augusto de Lima 1715, 30190-002 Belo Horizonte, MG, Brasil
}

From complete mitochondrial DNA sequence of Fasciola hepatica available in Genbank, specific primers were designed for a conserved and repetitive region of this trematode. A pair of primers was used for diagnosis of infected Lymnaea columella by F. hepatica during the pre-patent period simultaneously with another pair of primers which amplified the internal transcribed spacer (ITS) region of rDNA from L. columella in a single Multiplex-PCR. The amplification generated a ladder band profile specific for $\mathrm{F}$. hepatica. This profile was observed in positive molluscs at different times of infection, including adult worms from the trematode. The Multiplex-PCR technique showed to be a fast and safe tool for fascioliasis diagnosis, enabling the detection of F. hepatica miracidia in L. columella during the pre-patent period and identification of transmission areas.

Key words: Fasciola hepatica - Lymnaea columella - multiplex polymerase chain reaction - DNA mitochondrial - diagnosis

Fascioliasis is regarded to be one of the most important parasitic diseases in domestic ruminants of economical importance and its aethiological agent, Fasciola hepatica (Linnaeus, 1758), is a cosmopolitan trematode in areas of bovine, caprine, ovine, and buffaloes breading (Lessa et al. 2000). Great economical losses are believed to be caused by such parasitism, leading to the decrease of meat and milk production as well as to high mortality rates in several countries in the world (Saleha 1991). Human cases have been reported in the five continents (MasComa et al. 2001), but man participates as an accidental host in the parasite life cycle.

F. hepatica intermediate host snails belong to the genus Lymnaea (Saleha 1991). Lymnaeidae are widely distributed fresh water hermaphrodite pulmonata with a dextral shell and without operculum. There are over 20 species of the genus and many of them are F. hepatica and $F$. gigantica transmitters. F. hepatica Brazilian intermediate hosts are: L. columella (Say, 1817) and L. viatrix (Orbigny, 1835). The distribution of $L$. columella in South America has been reported in Venezuela, Colombia, and Equator, to the Andes east (Paraense 1982a). Prepelitchi et al. (2003) reported the first evidence of natural infection of $L$. columella with $F$. hepatica in Argentina. In Brazil, the geographical distribution of L. columella is quite broad and it has been reported to be present in the following states: Rio Grande do Sul, Santa Catarina, Paraná, São Paulo, Rio de Janeiro, Minas Gerais, Goiás, Distrito Federal, Mato Grosso, Mato Grosso do Sul, Amazonas, and Bahia (Paraense 1982a, b, 1983, 1986). In Minas Gerais, in the municipality of Itajubá, Silva et al. (1995) remarked the first finding of $L$. columella naturally infected by $F$. hepatica.

Partial financial support: Fapemig

Corresponding author: Fax: +55-31-3295.3115. E-mail: omar@cpqrr.fiocruz.br

Received 21 January 2004

Accepted 29 April 2004
Traditional methods of F. hepatica detection in L. columella are usually performed by exposing the snails to light and/or posterior dissection, through which cercariae may be observed (Souza et al. 2002). Such method does not allow the infection diagnosis during the pre-patent period, compromising field trials.

Molecular techniques have been extensively used as diagnosis tools. Up to the present, most of the works have reported the use of radioactive probes which hybridise with a ribosomal RNA (ribonucleic acid) region from F. hepatica (Shubkin et al. 1992, Heussler et al. 1993, Rognlie et al. 1994, Kaplan et al. 1995), but such methods are time-consuming besides demanding manipulation of radioactive materials.

The Multiplex-PCR technique consists of using specific primers, simultaneously, in a single reaction, under high stringency conditions. It has been widely used for detection and identification of a wide range of organisms, including: yeast strains; measles virus from clinical samples; isomorphic species from the complex Anopheles dirus; free-living Amoeba in the environment; and snails from the group Bulinus africans (Fujita et al. 1993, Mosqueira et al. 2002, Pelandakis \& Pernen 2002, Stohard et al. 2002).

The present work was aimed at designing a pair of primers for the conserved and repetitive region of mitochondrial DNA from $F$. hepatica that could be used to detect infections by this trematode. Those primers were simultaneously used in a Multiplex-PCR with another pair of primers that amplified the internal transcribed spacer (ITS) region of rDNA of the trematode and molluscs which worked as an internal control.

\section{MATERIALS AND METHODS}

Parasites, snails, and experimental infections - Adult worms and eggs from $F$. hepatica (Uruguai strain) were obtained from experimentally infected rabbit gall bladder. The eggs were incubated at $27^{\circ} \mathrm{C}$ in distilled water in the dark for 12-14 days and then exposed to artificial light for approximately $2 \mathrm{~h}$, at $28 \pm 1^{\circ} \mathrm{C}$, for miracidia eclosion. Miracidia were collected with a micropipette under a stereomi- 
croscope and then transferred to cell culture plate with 24 wells of the $2.5 \mathrm{ml}$ liquid capacity. Into each well one $L$. columella snail was introduced together with five newecloded miracidia and the total volume was completed with distilled water. The dishes were covered with a lid for approximately $2 \mathrm{~h}$ in order to ensure that the snails were totally immersed in distilled water. The snails were killed at different times of infections $(1,5,7,10,15,20$, and 34 days). The specimens of $L$. columella, measuring approximately 3-5 mm length, were reared and kept at the Snail Rearing of Centro de Pesquisas René Rachou-Fiocruz, according to Souza and Magalhães (2000). F. hepatica adult worms were frozen and kept at $-70^{\circ} \mathrm{C}$. The species Cercaria macrogranulosa and Cercaria caratinguensis, obtained from snails collected at Barreiro de Cima, city of Belo Horizonte, state of Minas Gerais, were also included in this study.

DNA extraction - Total DNA was extracted from the snails body, a cercariae pool, and adult worms, using the Genomic DNA Purification Kit Wizard (Promega). Briefly, the material was mechanically disrupted in $200 \mu \mathrm{l}$ of nucleic lysis solution and incubated overnight with $50 \mu \mathrm{g} / \mathrm{ml}$ proteinase $\mathrm{K}$. Thereafter, $80 \mu \mathrm{l}$ of protein precipitation solution was added to the initial mix. The mixture was placed in vortex for 10-20 s and centrifuged at 14,000 rpm for 5 $\min$. The supernatant was transferred to a microcentrifuge tube containing $300 \mu \mathrm{l}$ of isopropanol at room temperature precipitation. The mixture was gently mixed by inversion for $20 \mathrm{~min}$ and centrifuged at 14,000 rpm for $5 \mathrm{~min}$. The DNA pellet was washed with $300 \mu 1$ of $70 \%$ ethanol and centrifuged for $10 \mathrm{~min}$. The pellet was treated with 50 $\mu \mathrm{l}$ of DNA rehydration solution for $30 \mathrm{~min}$ at $65^{\circ} \mathrm{C}$ and stored at $-20^{\circ} \mathrm{C}$.

Primers design - From the complete mitochondrial DNA sequence of $F$. hepatica (Le et al. 2001), available in NCBI (National Center for Biotechnology Information) Genbank, specific primers were designed for the conserved and repetitive region of mitochondrial DNA of the trematode, which consisted of identical tandem repeats of 85 nucleotides, rich in $\mathrm{G}$ and $\mathrm{C}$. The designed primer pair was: FASCR (5' CCA AAT AAA TAG ATC AGC CC 3') and FASCF (5' ATA TTAAGA GTT GTG CCC C 3'). Annealing temperature was set to be $56^{\circ} \mathrm{C}$.

Multiplex-PCR and PCR product analysis - Multiplex-PCR consisted of using simultaneously 2 pairs of primers in a single reaction, under high stringency conditions. The primers FASCR and FASCF flanked a region of mtDNA from $F$. hepatica, while the other pair, ETTS1 and ETTS2 (Kane \& Rollison 1994), flanked the ITS region of the trematode and the mollusc, which worked as an internal control. PCR amplification was carried out in a final volume of $10 \mu \mathrm{l}$, with $1 \mathrm{ng}$ target DNA, 5 pmol of each primer, $200 \mu \mathrm{M}$ each desoxyribonucleotide triphosphate (dNTP- PROMEGA), 0.8 units TaqDNA polymerase (Cenbiot RS) in a buffer containing $10 \mathrm{mM}$ Tris - $\mathrm{HCl}, \mathrm{pH}$ $8.5,50 \mathrm{mM} \mathrm{KCl}, 1.5 \mathrm{mM} \mathrm{MgCl} 2$. Afterwards, each reaction tube was covered with $20 \mu \mathrm{l}$ of mineral oil in order to avoid evaporation during PCR cycles. The samples were amplified in thermocycler M J Research, Inc; model PTC-100 (Programmable Thermal Controller). The program used involved 26 cycles: denaturation step at $95^{\circ} \mathrm{C}$ for $3 \mathrm{~min}$, annealing at $56^{\circ} \mathrm{C}$ for $1 \mathrm{~min}$ and extension at $72^{\circ} \mathrm{C}$ for 1 min, followed by 25 cycles with denaturation step at $95^{\circ} \mathrm{C}$ for $45 \mathrm{~s}$, annealing at $56^{\circ} \mathrm{C}$ for $1 \mathrm{~min}$ and extension at $72^{\circ} \mathrm{C}$ for $1 \mathrm{~min}$, and the last cycle extension period time was changed to $5 \mathrm{~min}$. A negative control (no DNA) was included in all the experiments. PCR products were visualized on $6 \%$ silver stained polyacrylamide gels. The gels were photographed using a digital camera.

Reaction sensitivity to detect F. hepatica in L. columella - To establish the reaction sensitivity for $F$. hepatica detection in L. columella, amplification of mtDNA was performed. DNA was extracted from 1 to 10 miracidia of $F$. hepatica and 1 negative $L$. columella. DNA from such organisms was quantified by spectrophotometry. DNA from a variable number of miracidia was mixed to a constant amount of total DNA from negative snails, in order to simulate the infection. Thus, DNA from negative snails $(7 \mathrm{ng} / \mu \mathrm{l})$ was mixed with DNA extracted 10 miracidia from $F$. hepatica $(9.8 \mathrm{ng} / \mu \mathrm{l}), 5$ miracidia $(4.8 \mathrm{ng} / \mu \mathrm{l}), 3$ miracidia $(3.1 \mathrm{ng} / \mu \mathrm{l})$, and $1 \mathrm{miracidia}(0.8 \mathrm{ng} / \mu \mathrm{ml})$. Afterwards, PCR was performed as described above. PCR products were visualised on $6 \%$ silver stained polyacrylamide gels.

\section{RESULTS}

Multiplex-PCR - The designed primers generated a ladder band profile, specific for $F$. hepatica (Fig. 1 lane 2). Simultaneous use of species-specific primers directed to $F$. hepatica and the ITS region allowed us to diagnose infected $L$. columella with the trematode after: 1 day of infection (Fig. 1, lanes 4, 5); 5 days (Fig. 1, lanes 6, 7), 10 days; (Fig. 1, lane 8); 15 days (Fig. 1, lane 9); 20 days (Fig. 1, lane 10), and 34 days after infection (Fig. 1, lane 11). The characteristic ladder observed in Fig. 1 shows bands with intervals of 85 nucleotides. Such pattern mirrors the amplification of a tandem repeat DNA region, and it was ob-

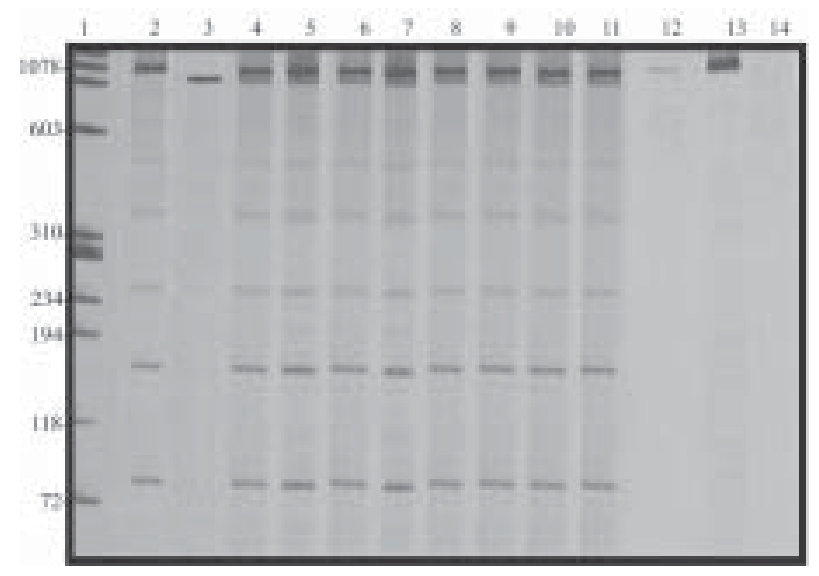

Fig. 1: $6 \%$ silver stained polyacrylamide gels showing mtDNA amplification of Fasciola hepatica by Multiplex-PCR. Lanes - 1: molecular weight pattern (ØX174 restriction enzyme Hae III digestion); 2: adult worm of $F$. hepatica; 3: negative L. columella; 4 , 5: L. columella after 1 day of infection; 6, 7: L. columella after 5 days of infection; 8: L. columella after 10 days of infection; 9: $L$. columella after 15 days of infection; 10: L. columella after 20 days of infection; 11: L. columella after 34 days of infection; 12: Cercaria macrogranulosa; 13: C. caratinguensis; 14: negative control (no DNA) 
served in all infected snails (Fig. 1, lanes 4 - 11), in adult worms from $F$. hepatica (Fig. 1, lane 2) and it was absent in non-exposed snails to miracidia (Fig. 1, lane 3). In this lane, only the ITS of rDNA from L columella could be visualised (1200 pb). In positive snails, the ITS of rDNA from $F$. hepatica (1300 pb) and L. columella (1200 pb), and the specific bands generated by amplification of mtDNA from $F$. hepatica can be observed.

Reaction sensitivity of F. hepatica detection in L. columella - The reaction showed to be sensitive, detecting 1 miracidia $(0.8 \mathrm{ng} / \mu \mathrm{l})$ from $F$. hepatica (Fig. 2, lanes 10, 11) in the presence of the snail DNA $(7 \mathrm{ng} / \mu \mathrm{l})$.

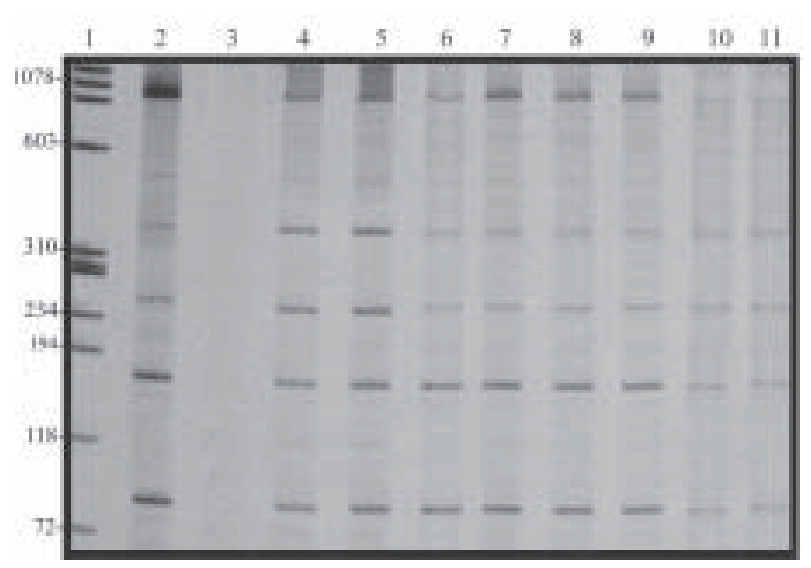

Fig. 2: $6 \%$ silver stained polyacrylamide gels, showing the sensitivity of the primers FASCR and FASCF for detecting Fasciola hepatica through polymerase chain reaction amplification. Lanes - 1 : molecular weight pattern (ØX174 restriction enzyme Hae III digestion); 2: adult worm of $F$. hepatica; 3 : negative snail DNA; 4, 5: negative snail mixed with 1 miracidia; 6,7 : negative snail with 3 miracidia; 8, 9: negative snail with 5 miracidia; 10, 11: negative snail with 10 miracidia

\section{DISCUSSION}

In the present work, primers were designed in order to detect the presence of $F$. hepatica in L. columella snails in the pre-patent period of infection by Multiplex-PCR, enabling a fast, sensitive and safe diagnosis of the trematode into its invertebrate host.

Diagnosis of $L$. columella infection by $F$. hepatica is routinely performed either by exposing the snails to light in order to observe cercariae or by dissecting them to visualize cercariae, sporocysts, and redia, mainly when located into the digestive gland. When the sporocysts are young and located in the cephalopodal region, or when the snails are collected in the field and probably infected with different trematode (Loker et al. 1982), it is impossible to diagnose the trematode through those methods due to the similarity of young stages. Another difficulty arises when the snails collected in the field die before their arrival in laboratory, precluding any chance of trematode detection. Such remarks are quite important once the snails should be kept in laboratory and periodically observed, in order to obtain reliable results. In addition, during the maintenance period, the snails may come to death before starting eliminating cercariae, and the diagnosis is once again compromised.
To overcome such constraints, molecular techniques have been used as auxiliary tools to detect $F$. hepatica in the invertebrate host. Other investigations, carried out so far, have used radioactive probes that hybridize with the ribosomal DNA region from $F$. hepatica (Shubkin et al. 1992, Heussler et al. 1993, Rognlie et al. 1994, Kaplan et al. 1995). These methods are long lasting and there is manipulation of radioactive material. Kaplan et al. (1997) used labeled probes and a chemiluminescent system to detect F. hepatica.

Here, we employed Multiplex-PCR, using 4 primers simultaneously in a single reaction, under high stringency conditions, enabling an specific DNA amplification from the snail and the trematode. This method was also highly sensitive, detecting specific $F$. hepatica infection in early pre-patent periods. Multiplex-PCR, besides being specific, provides an efficient internal control for the amplification of DNA from the mollusc.

The designed primers were specific for $F$. hepatica detection as demonstrated by the band profiles obtained from snails infected with this trematode and other ones (C. macrogranulosa and C. caratinguenses, for instance), commonly found in L. columella.

The profile with specific bands obtained through Multiplex-PCR was observed in positive snails at the different times of infection proposed here, including adult worms. This methodology has been applied to detect and differentiate several other organisms (Mosquera et al. 2002, Patsoula et al. 2003, Rivera et al. 2003, Fettene \& Temu 2003). The high sensitivity of the test showed that the detection threshold of the parasite DNA was 1 miracidia and it may be used to detect infections during the prepatent period, as demonstrated by the time intervals studied here. This methodology will be useful in field trials, providing a more realistic picture of the epidemiology of the disease.

\section{REFERENCES}

Fettene M, Temu EA 2003. Species-specific primer for identification of Anopheles quadriannulatus sp. B (Diptera: $\mathrm{Cu}-$ licidae) from Ethiopia using a multiplex polymerase chain reaction assay. J Med Entomol 40: 112-115.

Fujita SI, Senda Y, Nakaguchi S, Hashimoto T, Heussler V, Kaufmann H, Strahm D, Liz J, Dobbelaere D 1993. DNA probes for the detection of Fasciola hepatica in snails. Mol Cell Probes 7: 261-267.

Heussler V, Kaufmann H, Strahm D, Liz J, Dobbelaere D 1993. DNA probes for the detection of Fasciola hepatica in snails. Mol Cell Probes 7:261-267.

Kane RA, Rollison D 1994. Repetitive sequences in the ribosomal DNA internal transcribed spacer of Schistosoma haematobium, Schistosoma intercalatum and Schistosoma mattheii. Mol Biol Parasit 63: 153-156.

Kaplan RM, Dame JB, Reddy GR, Courtney CH 1995. A repetitive DNA probe for the sensitive detection of Fasciola hepatica infected snails. Int J Parasitol 25: 601-610.

Kaplan RM, Dame JB, Reddy GR, Courtney CH 1997. The prevalence of Fasciola hepatica in its snail intermediate host determined by DNA probe assay. Int J Parasitol 27: 1585-1593.

Le TH, Blair D, McManus DP 2001. Complete DNA sequence and gene organization of the mitochondrial genome of the liverfluke, Fasciola hepatica L. (Platyhelminthes; Trema- 
toda). Parasitology 123: 609-621.

Lessa CSS, Scherer PO, Vasconcelos MC, Freire LS, Santos JAA, Freire NMS 2000. Registro de Fasciola hepatica em equinos (Equus caballus), caprinos (Capra hircus) e ovinos (Ovis aries), no município de Itaguaí, Rio de Janeiro, Brasil. Rev Bras Ciência Vet 7: 63-64.

Loker ES, Bayne CJ, Buckley PM, Kruse KT 1982. Ultrastructure of encapsulation of Schistosoma mansoni mother sporocysts by hemocytes of juveniles of the 10-R2 strain of Biomphalaria glabrata. J Parasitol 68: 84-94.

Mas-Coma S, Funatsu IR, Bargues MD 2001. Fasciola hepatica and lymnaeid snails occurring at very high altitude in South America. Parasitology 123 (Suppl.): 115-127.

Mosquera Mdel M, de Ory F, Moreno M, Echevarria JE 2002. Simultaneous detection of measles virus, rubella virus, and parvovirus B19 by using multiplex PCR. J Clin Microbiol 40: 111-116.

Paraense WL 1982a. Lymnaea viatrix and L. columella in the Neotropical Region: a distributional outline. Mem Inst Oswaldo Cruz 77: 181-188.

Paraense WL 1982b. Lymnaea rupestris sp. n. from Southern Brazil (Pulmonata - Lymnaeidae). Mem Inst Oswaldo Cruz 77: 437-443.

Paraense WL 1983. Lymnaea columella in Northern Brazil. Mem Inst Oswaldo Cruz 78: 477-482.

Paraense WL 1986. Lymnaea columella: two new brazilian localities in the states of Amazonas and Bahia. Mem Inst Oswaldo Cruz 81: 121-123.

Patsoula E, Spanakos G, Sofianatou D, Parara M, Vakalis NC 2003. A single-step, PCR-based method for the detection and differentiation of Plasmodium vivax and $P$. falciparum. Ann Trop Med Parasitol 97: 15-21.

Pelandakis M, Pernin P 2002. Use of multiplex PCR and PCR restriction enzyme analysis for detection and exploration of the variability in the free-living amoeba Naegleria in the environment. Appl Environ Microbiol 68: 2061-2065.

Rivera IN, Lipp EK, Gil A, Choopun N, Huq A, Colwell RR
2003. Method of DNA extraction and application of multiplex polymerase chain reaction to detect toxigenic Vibrio cholerae $\mathrm{O} 1$ and $\mathrm{O} 139$ from aquatic ecosystems. Environ Microbiol 5: 599-606.

Prepelitchi L, Kleiman F, SM Pietrokovsky SM, Moriena RA, Racioppi O, Alvarez J, Wisnivesky-Colli C 2003. First report of Lymnaea columella Say, 1817 (Pulmonata: Lymnaeidae) naturally infected with Fasciola hepatica (Linnaeus, 1758) (Trematoda: Digenea) in Argentina. Mem Inst Oswaldo Cruz 98: 889-891.

Rognlie MC, Dimke KL, Knapp SE 1994. Detection of Fasciola hepatica in infected intermediate hosts using RT-PCR. J Parasitol 80: 748-755.

Saleha AA 1991. Liver fluke desease (fascioliasis): epidemiology economic impact and public health significance. Southeast Asian J Trop Med Public Health 22 (Suppl.): 361-364.

Shubkin CD, White MW, Abrahamsen MS, Rognlie MC, Knapp SE 1992. A nucleic acid-based test for detection of Fasciola hepatica. J Parasitol 78: 817-821.

Silva RE, Lima WS, Caldas WS, Cury MC, Malacco AF 1995. Primeiro encontro de Lymnaea columella (Say, 1817) naturalmente infectada por estádios intermediários de Fasciola hepatica (Linnaeus, 1758) na cidade de Itajubá, MG. In XIV Congresso Brasileiro de Parasitologia, p. 205.

Souza CP, Magalhães KG 2000. Rearing of Lymnaea columella (Say,1817), intermediate host of Fasciola hepatica (Linnaeus, 1758). Mem Inst Oswaldo Cruz 95: 739-741.

Souza CP, Magalhães KG, Jannotti Passos LK, Pereira dos Santos GC, Ribeiro F, Katz N 2002. Aspects of the maintenance of the life cycle of Fasciola hepatica in Lymnea collumela in Minas Gerais, Brazil. Mem Inst Oswaldo Cruz. 97: 407-410.

Stothard JR, Llewellyn-Hughes J, Griffin CE, Hubbard SJ, Kristensen TK, Rollinson D 2002. Identification of snails within the Bulinus africanus group from East Africa by multiplex SNaPshot trade mark analysis of single nucleotide polymorphisms within the cytochrome oxidase subunit I. Mem Inst Oswaldo Cruz 97 (Suppl. 1): 31-36. 